\title{
MUTU SEMI REFINED CARRAGEENAN (SRC) YANG DIPROSES MENGGUNAKAN AIR LIMBAH PENGOLAHAN SRC YANG DIDAUR ULANG
}

\author{
Jamal Basmal*, Bagus Sediadi Bandol Utomo*), dan Bakti Berlyanto Sedayu*)
}

\begin{abstract}
ABSTRAK
Telah dilakukan penelitian mutu semi refined carrageenan (SRC) yang diproses menggunakan air limbah pengolahan SRC yang didaur ulang. Air limbah pengolahan SRC terlebih dahulu dinetralkan, dikoagulasi, diflokulasi, dan disaring menggunakan zeolit dan arang aktif. Air yang sudah diolah tersebut selanjutnya digunakan untuk proses pengolahan SRC berikutnya. Untuk melihat optimalisasi penggunaan air hasil daur ulang terhadap penurunan mutu fisiko kimia SRC yang dihasilkan, dilakukan 5 kali daur ulang berturut-turut. Dari penelitian ini disimpulkan bahwa limbah cair pengolahan SRC dapat digunakan kembali untuk pengolahan SRC berikutnya. Berdasarkan parameter kekuatan gel karaginan yang dihasilkan, ternyata terjadi peningkatan kekuatan gel dari $806 \mathrm{~g} / \mathrm{cm}^{2}$ menjadi $1147 \mathrm{~g} / \mathrm{cm}^{2}$ untuk SRC yang diolah/dicuci dengan air limbah yang telah mengalami 4 kali proses daur ulang. Pada tahap ini SRC mempunyai kadar abu $16,0 \%$, abu tak larut asam $0,04 \%$, kadar sulfat $3,9 \%$, dan kadar air $12,3 \%$.
\end{abstract}

\section{ABSTRACT: Quality of semi refined carrageenan (SRC) processed using recycled SRC waste water. By: Jamal Basmal, Bagus Sediadi Bandol Utomo and Bakti Berlyanto Sedayu}

Study on the quality of semi refined carrageenan (SRC) processed using recycled SRC waste water has been carried out. The waste water was firstly neutralized, coagulated, flocculated and filtered using zeolite and active charcoal. The treated water was then used in the next batch of SRC processing. To optimize the use of recycled waste water, the physico-chemical quality of the resulted SRC was monitored in 5 consecutive processes. Results showed that the waste water can be re-used for the next batch of SRC production. By using 4 consecutive recycled water, the gel strength improved from $806 \mathrm{~g} / \mathrm{cm}^{2}$ to $1147 \mathrm{~g} / \mathrm{cm}^{2}$ with ash content of $16.0 \%$, acid insoluble ash of $0.04 \%$, sulfate content of $3.9 \%$, and moisture content of $12.3 \%$.

KEYWORDS: recycling process, waste water, quality, carrageenan

\section{PENDAHULUAN}

Bahan bantu utama dalam proses pengolahan semi refined carrageenan (SRC) adalah air. Oleh karena itu, tanpa ketersediaan air yang cukup akan sulit didapatkan produk SRC yang bermutu tinggi. $\mathrm{Di}$ samping untuk membuang kotoran yang ada pada permukaan thallus, air juga digunakan sebagai pelarut bahan kimia yang ditambahkan untuk memperbaiki kualitas produk. Jumlah air yang digunakan dalam proses pencucian rumput laut dapat mencapai 10 kali bobot kering rumput laut. Air yang sudah dipakai untuk pembersihan rumput laut banyak mengandung lumpur, sisa-sisa garam, serta mineral lainnya, sehingga tidak layak untuk digunakan kembali dalam proses pencucian rumput laut. Di sisi lain dalam proses pembuatan produk semi refined carrageenan (SRC) dibutuhkan air dalam jumlah yang sangat banyak, yaitu sekitar 40 kali bobot kering rumput laut.
Mutu SRC sangat ditentukan oleh teknik pengolahannya seperti suhu, waktu, dan ketepatan konsentrasi bahan kimia yang diberikan serta kualitas air yang digunakan. Karaginan biasanya mengandung garam sodium atau potasium yang sengaja ditambahkan pada proses pengolahannya untuk meningkatkan mutu karaginan. Garam-garam tersebut ditambahkan untuk mengubah $\mu$-karaginan menjadi kappa-karaginan atau $v$-karaginan menjadi iotakaraginan. Tetapi pemberian ion $\mathrm{K}^{+}$atau $\mathrm{Na}^{+}$yang kurang tepat dapat menyebabkan kualitas SRC yang diharapkan tidak tercapai.

Air bekas pengolahan rumput laut menjadi SRC kaya akan mineral organik maupun anorganik seperti ion $\mathrm{K}^{+}, \mathrm{Na}^{+}, \mathrm{Cl}^{-}, \mathrm{Ca}^{++}$, dan $\mathrm{OH}^{-}$yang berpotensi meningkatkan kualitas produk SRC. Sedayu et al. (2007) menemukan bahwa air hasil daur ulang pengolahan limbah cair SRC mampu menurunkan nilai

Peneliti pada Balai Besar Riset Pengolahan Produk dan Bioteknologi Kelautan dan Perikanan, DKP 
$\mathrm{pH}$, kekeruhan, bau, dan warna air limbah cair SRC. Pencampuran karaginan dengan ion kalium akan menghasilkan dua komponen utama yaitu lambda karaginan sebagai fraksi terlarut dan kappa-karaginan sebagai fraksi yang tidak larut. Fraksi yang terlarut tidak dapat membentuk gel sedangkan fraksi yang tidak larut akan membentuk gel (Towle, 1973). Suryaningrum et al. (2003) menyatakan bahwa perlakuan alkali $(\mathrm{KOH})$ pada rumput laut sebelum proses ekstraksi dapat meningkatkan rendemen, kekentalan, dan kekuatan gel kappa-karaginan yang dihasilkan.

Tujuan penelitian ini adalah untuk meningkatkan efisiensi pemakaian air dalam pengolahan rumput laut Eucheuma cottonii menjadi produk SRC sehingga teknik ini dapat diterapkan di daerah-daerah yang potensial menghasilkan E. cottonii tetapi sulit untuk mendapatkan air bersih yang cukup.

\section{BAHAN DAN METODE}

\section{Bahan}

Jenis rumput laut yang digunakan dalam penelitian ini adalah E. cottonii asal Kabupaten Sumenep. Rumput laut yang berumur antara $40-45$ hari dipanen oleh petani kemudian dikeringkan di bawah sinar matahari hingga kadar air mencapai 35\%. Rumput laut tersebut kemudian dikirim ke Balai Besar Riset Pengolahan Produk dan Bioteknologi di Jakarta untuk digunakan dalam penelitian ini.

Untuk mencuci rumput laut yang akan diolah menjadi SRC digunakan air limbah pengolahan SRC yang merupakan hasil proses daur ulang. Air limbah pengolahan SRC yang digunakan adalah air limbah pencucian ke-2, ke-3, dan ke-4 yang dikumpulkan dalam satu bak. Setelah air limbah dikumpulkan

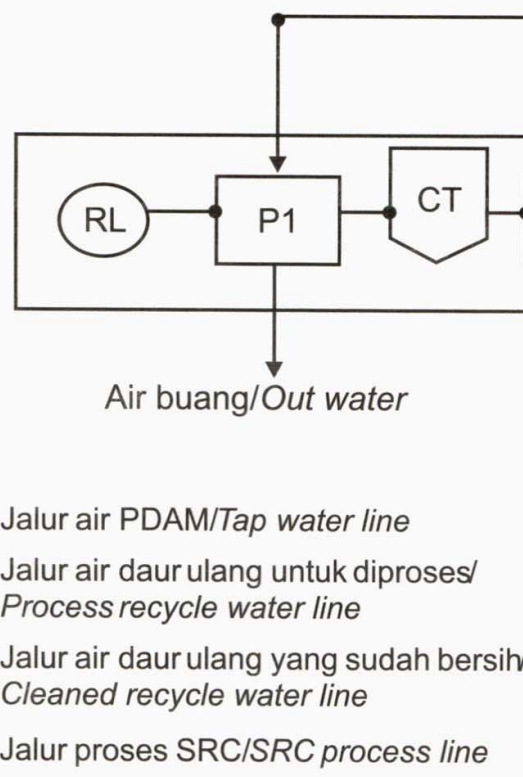

Keterangan/Explanation:

1. $\mathrm{RL}=$ Rumput laut kering/Dried seaweed

2. $\mathrm{P} 1=$ Pencucian pertama/First washing

3. $\mathrm{CT}=$ Pemasakan dalam larutan alkali/boiling in hot alkali solution

4. P2 = Pencucian kedua/Second washing

5. P3 = Pencucian ketiga/Third washing

6. $\mathrm{P} 4=$ Pencucian keempat/Fourth washing

7. $\mathrm{TP}=$ Air PDAM/Tap water

8. $W P 1=$ Perlakuan pengolahan air tahap $\mathrm{I} /$ First water treatment

9. $\mathrm{WP} 2=$ Perlakuan pengolahan air tahap II/Second water treatment

10. WP3 = Perlakuan pengolahan air tahap III/Third water treatment

11. $W R=$ Air bersih daur ulang/Recycled water

12. WP1....WP3 = Alur proses limbah cair/Flow chart of water recycling

Gambar 1. Skema pengolahan SRC menggunakan air daur ulang.

Figure 1. Scheme of SRC processing using recycled water. 
menjadi satu kemudian dilakukan pengaturan $\mathrm{pH}$ dan diikuti dengan proses koagulasi, flokulasi, filtrasi, dan aerasi, dan selanjutnya didaur ulang sebagai pencuci rumput laut pada proses berikutnya.

\section{Metode}

Dalam pembuatan produk SRC, rumput laut dimasak dalam larutan alkali $(\mathrm{KOH})$ panas $\left(75-80^{\circ} \mathrm{C}\right)$ dengan konsentrasi $8 \%$ selama 3 jam. SRC yang sudah dimasak dalam larutan alkali panas ini kemudian dicuci menggunakan air PDAM (perlakuan kontrol). Air cucian pertama (P1) dibuang, sedangkan air limbah pencucian berikutnya P2, P3, dan P4 dikumpulkan untuk diproses lebih lanjut seperti terlihat pada Gambar 1. Air yang sudah diolah kemudian digunakan untuk mencuci SRC berikutnya (P1, P2, dan P3). Proses pengolahan air limbah dan pemanfaatannya kembali dilakukan berturut-turut hingga 5 kali pengolahan SRC. Pada setiap batch pengolahan SRC, air bersih (PDAM) hanya digunakan pada proses pencucian ke-4 ( $\mathrm{P} 4)$. Setiap kali proses pengolahan SRC digunakan rumput laut E. cottonii kering sebanyak $40 \mathrm{~kg}$. Percobaan dilakukan dengan 3 ulangan.

Untuk melihat kualitas SRC yang dihasilkan dari setiap kali penggunaan air hasil daur ulang, dilakukan uji mutu SRC yang dihasilkan menggunakan parameter kekuatan gel dengan dan tanpa $\mathrm{KCl}$ (Marine Colloid, 1977), kadar sulfat (Anon., 1986) kadar abu, kadar abu tak larut asam, kadar air (Horwitz, 1980), dan nilai kekentalan menggunakan alat Brookfields viskometer $\left(1,5 \%\right.$ karaginan, $\left.76^{\circ} \mathrm{C}\right)$.

\section{HASIL DAN BAHASAN}

\section{Rendemen}

Rendemen tepung karaginan sangat dipengaruhi oleh beberapa faktor yang meliputi umur panen, bibit, kualitas perairan tempat budidaya, dan teknik pengeringan rumput laut. Di samping itu juga dipengaruhi oleh kadar air, kadar kotoran (lumpur, lumut, pasir, serpihan tali, dan sebagainya), dan nilai clean anhydrous weed (CAW). Untuk mendapatkan rendemen SRC lebih besar dari 30\%, kadar air awal rumput laut kering sebelum diolah harus berada dalam kisaran $32-35 \%$, kadar kotoran $\leq 2 \%$. Pada penelitian ini kadar air awal rumput laut kering asal Madura adalah $\pm 39 \%$ dengan kadar kotoran $\pm 5 \%$. Di samping faktor yang disebutkan di atas, teknik pengolahan juga berperan sangat penting seperti perlakuan suhu, waktu ekstraksi, dan konsentrasi larutan $\mathrm{KOH}$ yang berpengaruh terhadap rendemen yang dihasilkan. Dalam penelitian ini rendemen yang diperoleh berkisar antara $21-28,5 \%$, dengan nilai terendah ditemukan pada perlakuan air daur ulang ke3 sebesar $21 \%$ dan yang tertinggi pada penggunaan air daur ulang ke-5 sebesar 28,5\% (Gambar 2).

Terjadinya fluktuasi rendemen SRC yang dihasilkan pada setiap perlakuan mungkin disebabkan oleh kecepatan reaksi ion $\mathrm{K}^{+}$dari $\mathrm{KOH}$ dan ion lain yang berasal dari kelebihan proses penetralan air daur ulang. Pada proses penetralan telah digunakan tawas $\left(\mathrm{Al}_{2}\left(\mathrm{SO}_{4}\right)_{3}\right)$ untuk mengendapkan kotoran yang ada dalam air bekas pencucian rumput laut sebelumnya. Tawas bereaksi dengan $\mathrm{KOH}$ membentuk $\mathrm{K}_{2} \mathrm{SO}_{4}$ dan $\mathrm{Al}(\mathrm{OH})_{3}$. Garam $\mathrm{K}_{2} \mathrm{SO}_{4}$ dan $\mathrm{Al}(\mathrm{OH})_{3}$ di dalam air terdisosiasi membentuk ion $\mathrm{K}^{+}, \mathrm{SO}_{4}{ }_{4}^{2-}$, dan $\mathrm{Al}^{3+}$. Ionion tersebut selama proses pencucian akan bereaksi dengan karaginan sehingga terjadi penambahan bobot karaginan yang dihasilkan.

Adanya perbedaan penetrasi ion-ion tersebut pada setiap perlakuan mungkin disebabkan oleh bervariasinya jumlah ion-ion tersebut di dalam air hasil daur ulang. Hasil penelitian menunjukkan bahwa rendemen SRC meningkat setelah proses pencucian menggunakan air daur ulang yang ke-3. Pola yang serupa tampak pada jumlah padatan terlarut (TDS) air hasil daur ulang (Tabel 1); terlihat bahwa TDS untuk setiap air yang telah didaur ulang juga berfluktuasi dan terjadi peningkatan TDS setelah air limbah diproses yang ke-3 kalinya hingga proses daur ulang yang ke-5.

Hal lain yang mempengaruhi rendemen adalah jumlah kandungan air SRC untuk setiap perlakuan yakni semakin tinggi kadar air SRC akan semakin tinggi pula rendemen yang dihasilkan (Gambar 2). Penurunan kandungan air juga dipengaruhi oleh

Tabel 1. Total padatan terlarut air limbah pengolahan rumput laut.

Table 1. Total of dissolved solid of seaweed processing water waste

\begin{tabular}{ccccccc}
\hline \multirow{2}{*}{ Pengolahan/Process } & \multicolumn{6}{c}{ Total Padatan Terla rut (ppm)/Total Dissolved Solids (ppm) } \\
\cline { 2 - 7 } & \multicolumn{5}{c}{ Daur ulang ke/Number of recycling process } \\
\cline { 2 - 7 } & $\mathbf{0}$ & $\mathbf{1}$ & $\mathbf{2}$ & $\mathbf{3}$ & $\mathbf{4}$ & $\mathbf{5}$ \\
\hline Awal/Initial & 3975 & 3600 & 3625 & 3800 & 3200 & 3250 \\
Akhir/End & 1725 & 2500 & 2450 & 2475 & 2550 & 2750 \\
\hline
\end{tabular}




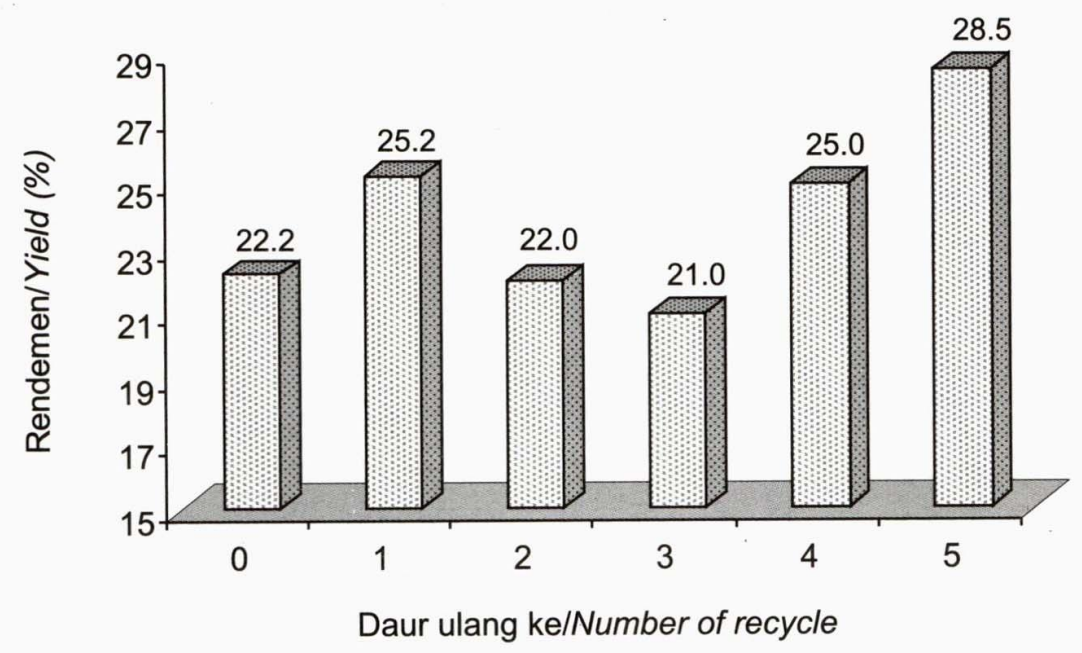

Gambar 2. Rendemen SRC yang diolah menggunakan air daur ulang.

Figure 2. Yield of SRC processed using recycled water.

banyaknya ion-ion $\mathrm{K}^{+}$dan $\mathrm{Al}^{3+}$ di dalam $\mathrm{SRC}$, karena ion-ion tersebut mampu mengikat air lebih kuat di dalam karaginan.

\section{Kekuatan gel dengan larutan $0,1 \% \mathrm{KCl}$}

Kekuatan gel SRC dengan $\mathrm{KCl}$ menggunakan air daur ulang sampai dengan 5 kali proses berkisar antara $811-1147 \mathrm{~g} / \mathrm{cm}^{2}$, sedangkan kontrol $806 \mathrm{~g} / \mathrm{cm}^{2}$. Kekuatan gel karaginan ini meningkat setara dengan jumlah proses daur ulang yang dilakukan dan mencapai nilai tertinggi pada perlakuan penggunaan air daur ulang ke-4 dan baru mengalami penurunan setelah penggunaan air daur ulang yang ke-5. Namun demikian, nilai kekuatan gel karaginan masih lebih tinggi dari perlakuan kontrol. Basmal et al. (2003) menyatakan bahwa kelebihan ion $\mathrm{K}^{+}$pada konsentrasi tertentu dapat meningkatkan kekuatan gel kappakaraginan. Pada Gambar 3 dapat dilihat nilai kekuatan gel karaginan.

Adanya peningkatan kekuatan gel SRC dengan $\mathrm{KCl}$ disebabkan air daur ulang banyak mengandung ion-ion $\mathrm{K}^{+}$, yang dapat meningkatkan gel karaginan yang dihasilkan. Dalam proses pembuatan karaginan jumlah kristal $\mathrm{KOH}$ yang dilarutkan adalah $8 \%$ dari volume air yang ditambahkan dengan harapan larutan $\mathrm{KOH}$ dapat memperbaiki mutu karaginan yang dihasilkan. Air limbah bekas pencucian rumput laut mempunyai nilai $\mathrm{pH} 12,0-12,4$. Untuk menurunkan nilai $\mathrm{pH}$ menjadi 9 digunakan $\mathrm{HCl}$. Reaksi $\mathrm{HCl}$ dengan kelebihan $\mathrm{KOH}$ di dalam limbah cair pengolahan

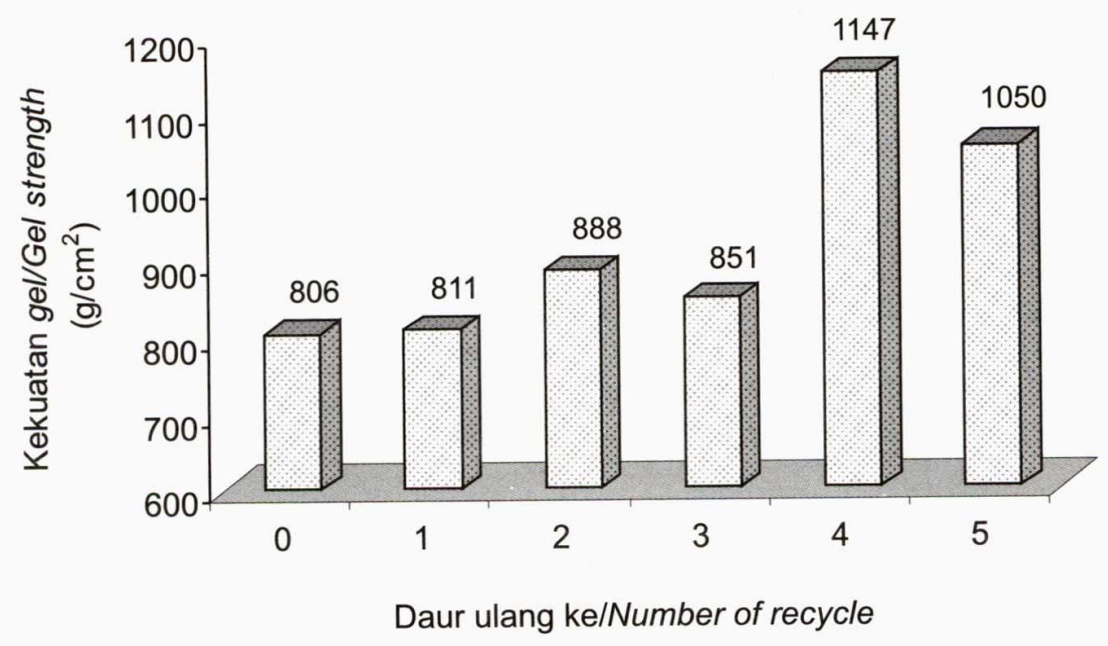

Gambar 3. Kekuatan gel (-KCl) SRC yang diolah menggunakan air daur ulang.

Figure 3. KCl-gel strength of SRC processed using recycled water. 
rumput laut akan membentuk garam $\mathrm{KCl}$, yang di dalam air akan terdisosiasi menjadi ion $\mathrm{K}^{+}$dan $\mathrm{Cl}^{-}$. lon $\mathrm{K}^{+}$yang terbentuk dapat meningkatkan kekuatan gel karaginan yang dihasilkan.

Garam-garam anorganik maupun organik memegang peranan penting dalam menghambat proses hidrasi karaginan misalnya $\mathrm{NaCl}$ dan $\mathrm{KCl}$ pada konsentrasi masing-masing 0,75 $\mathrm{M}$ dan 0,25 M (Towle, 1973). Terdapatnya garam sampai dengan $25 \%$ dalam larutan panas akan menyebabkan pengendapan kappa-karaginan. Bila konsentrasi garam yang ditambahkan lebih besar dari $25 \%$ maka ketiga jenis karaginan (kappa-, iota-, dan lambda karaginan) mengendap (Guiseley et al., 1980 dalam Luthfy, 1988). Salah satu jenis garam yang sudah dipakai untuk mengendapkan karaginan adalah KCl (Anon., 1991). Penurunan kelarutan karaginan dengan penambahan garam disebabkan oleh ion $\mathrm{K}^{+}$yang berfungsi untuk meningkatkan kekuatan ionik dalam rantai polimer karaginan sehingga terjadi penurunan tolakan elektrostatik di antara rantai polimer (Dea, 1979).

Menurut Glicksman (1969) pembentukan gel pada hidrokoloid dapat dilakukan dengan meningkatkan atau memperbesar gaya antar molekul terlarut dengan cara: menambah bahan yang tidak melarutkan koloid (ion $\mathrm{K}^{+}$), menguapkan zat pelarut, menambahkan bahan pengikat atau mengatur reaksi kimia yang bertujuan untuk mengurangi kelarutan koloid. Pembentukan gel dapat dipercepat dengan cara menambahkan larutan $\mathrm{KCl}$; namun demikian penggunaan $\mathrm{KCl}$ harus dibatasi karena dapat menimbulkan rasa pahit pada produk yang dihasilkan, dan penambahan $\mathrm{KCl}$ maksimum yaitu $0,1-0,2 \%$ (Towle, 1973). Selanjutnya dikatakan juga oleh Towle (1973) penambahan garam kalium lebih efektif dalam meningkatan kekuatan gel karaginan dibandingkan dengan penambahan garam amonium dan natrium, di samping itu garam natrium di dalam karaginan dapat menyebabkan terjadinya proses hidrasi yang lebih besar.

Pada Gambar 3 terlihat bahwa pada perlakuan penggunaan air daur ulang ke-4 terjadi peningkatan kekuatan gel, namun pada penggunaan air daur ulang ke-5 terjadi penurunan kekuatan gel karaginan. Rendahnya kekuatan gel karaginan pada penggunaan air daur ulang 1,2, dan 3 kemungkinan disebabkan jumlah ion $\mathrm{K}^{+}$yang ada dalam air daur ulang belum cukup untuk meningkatkan kekuatan gel karaginan. Sebaliknya pada penggunaan air daur ulang ke-5 terjadi penurunan kekuatan gel karaginan, yang mungkin disebabkan berkurangnya jumlah ion $\mathrm{K}^{+} \mathrm{di}$ dalam air daur ulang yang sudah dibersihkan sehingga mempunyai efek penurunan kekuatan gel.
Konsentrasi ion $\mathrm{K}^{+}$yang diperlukan dalam proses pembentukan gel minimal 0,007 M. Pada konsentrasi yang lebih rendah maka kappa-karaginan tidak dapat membentuk gel (Rochas \& Rinoudo, 1984 dalam Luthfy, 1988). Pada konsentrasi tersebut proses pembentukan gel kappa-karaginan akan terjadi dalam 2 tahap, sedangkan pada konsentrasi ion $\mathrm{K}^{+}$yang lebih besar dari 0,007 M proses pembentukan gel terjadi dalam 1 tahap. Selama konsentrasi ion $\mathrm{K}^{+}$ masih lebih besar dari 0,007M maka proses agregasi tidak tergantung pada konsentrasi ion $\mathrm{K}^{+}$tetapi lebih tergantung pada konsentrasi larutan ikatan rangkap tanpa adanya jembatan kation. Proses tersebut tidak memperlihatkan adanya jembatan kation antar pilinan ganda yang beragregasi dan fase larutan.

Kelarutan karaginan dipengaruhi oleh sifat hidrofilik molekul dari gugus ester sulfat dan unit galaktopiranosa. Kappa-karaginan memiliki gugus ester sulfat yang bersifat hidrofilik dalam jumlah yang rendah, tetapi mengandung 3,6-anhidro-galaktosa yang bersifat hidrofobik dalam jumlah yang lebih banyak, sehingga kappa-karaginan tidak larut dalam air dingin, sedangkan menurut Glicksman (1983) lambda-karaginan serta garam natrium dari kappakaraginan dan iota karaginan dapat larut dalam air dingin. Dengan adanya kation hidrofobik, misalnya ion kalium maka keseimbangan antara ion-ion yang larut dengan ion-ion yang terikat di dalam struktur karaginan dapat membentuk gel (Towle, 1973). Ion $\mathrm{K}^{+}$dalam pengolahan rumput laut menjadi produk SRC sangat penting dalam meningkatkan kualitas SRC khususnya kekuatan gel, sedangkan ion $\mathrm{OH}$ berfungsi untuk mengeliminir protein, lemak, dan vitamin. Kelebihan $\mathrm{Na}^{+}$dan $\mathrm{Ca}^{++}$dapat menyebabkan SRC yang dihasilkan mempunyai kualitas rendah karena ion-ion tersebut dapat menyebabkan gel menjadi mudah patah.

\section{Kekuatan gel tanpa KCl}

Kekuatan gel SRC tanpa penambahan $\mathrm{KCl}$ berkisar antara $112-229 \mathrm{~g} / \mathrm{cm}^{2}$ dengan nilai tertinggi ditemukan pada pemakaian air daur ulang ke-0 (kontrol) sedangkan terendah ditemukan pada pemakaian air daur ulang ke-4. Secara umum nilai kekuatan gel tanpa penambahan garam $\mathrm{KCl}$ menurun setara dengan perlakuan penggunaan air daur ulang. Pada Gambar 4 dapat dilihat perubahan nilai kekuatan gel karaginan tanpa penambahan garam $\mathrm{KCl}$. Salah satu faktor yang sangat berpengaruh dalam pembentukan kekuatan gel tanpa garam $\mathrm{KCl}$ adalah sejumlah ion sulfat yang terdapat pada karaginan. Semakin tinggi kandungan sulfat maka nilai kekuatan gel semakin menurun. Dalam proses daur ulang limbah kandungan sulfat dapat berasal dari proses koagulasi 


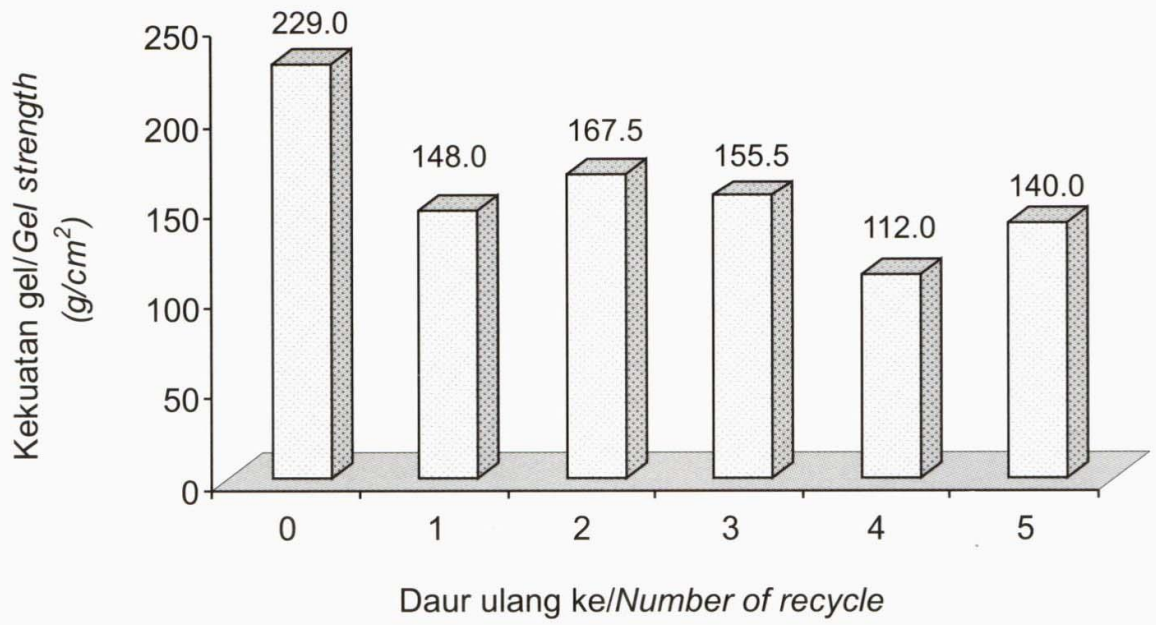

Gambar 4. Kekuatan gel SRC tanpa KCl yang diolah menggunakan air daur ulang.

Figure 4. Gel strength of $\mathrm{SRC}$ without $\mathrm{KCl}$ processed using recycled water.

yang menggunakan tawas. Fungsi tawas dalam proses daur ulang ini tidak hanya sebagai koagulan tetapi juga untuk menetralkan $\mathrm{pH}$ limbah cair. Dalam proses reaksinya tawas bereaksi dengan $\mathrm{KOH}$ membentuk $\mathrm{K}_{2} \mathrm{SO}_{4}$ dan $\mathrm{Al}(\mathrm{OH})_{3}$. Garam $\mathrm{K}_{2} \mathrm{SO}_{4}$ di dalam air terdisosiasi menjadi $\mathrm{K}^{+}$dan $\mathrm{SO}_{4}^{2-}$. Sulfat yang terbentuk ini selama proses pencucian rumput laut akan terserap kembali ke dalam thallus dan ion sulfat pada waktu proses pengeringan tidak menguap melainkan terendapkan di dalam thallus. Adanya sulfat bebas di dalam thallus ini kemungkinan akan bereaksi dengan karaginan kembali sehingga nilai kekuatan gel karaginan yang dihasilkan menjadi menurun dengan semakin banyaknya ion sulfat berpenetrasi ke dalam thallus pada saat proses pencucian dilakukan.

Adanya penurunan nilai kekuatan gel tanpa penambahan garam $\mathrm{KCl}$ kemungkinan disebabkan ion-ion $\mathrm{K}^{+}, \mathrm{Na}^{+}, \mathrm{Li}^{+}, \mathrm{Na}^{+}, \mathrm{Mg}^{2+}, \mathrm{Ca}^{2+}$, dan $\mathrm{Sr}^{2+}$ tidak cukup kuat untuk meningkatkan gel. Kekuatan gel karaginan akan sangat tergantung pada banyaknya ion positif seperti ion $\mathrm{K}^{+}$di dalam SRC. Urutan nilai kekuatan gel karaginan menggunakan ion adalah $\mathrm{K}^{+}$ $>\mathrm{Li}^{+}>\mathrm{Na}^{+}>\mathrm{Mg}^{2+}>\mathrm{Ca}^{2+}>\mathrm{Sr}^{2+}$ (Anon., 2007). Selanjutnya ion $\mathrm{K}^{+}$dan $\mathrm{Ca}^{2+}$, di dalam karaginan akan mombentuk ikatan double helix yang kuat pada kondisi dingin, tetapi se-baliknya pada suhu yang lebih tinggi dari titik leleh karaginan ikatan double helix akan melemah. Pada Gambar 5 dapat dilihat formasi pembentukan double helix.

\section{Kadar air}

Salah satu persyaratan mutu karaginan adalah nilai kadar air yang telah dipersyaratkan baik dalam perdagangan maupun standar (Food Chemical Codex)

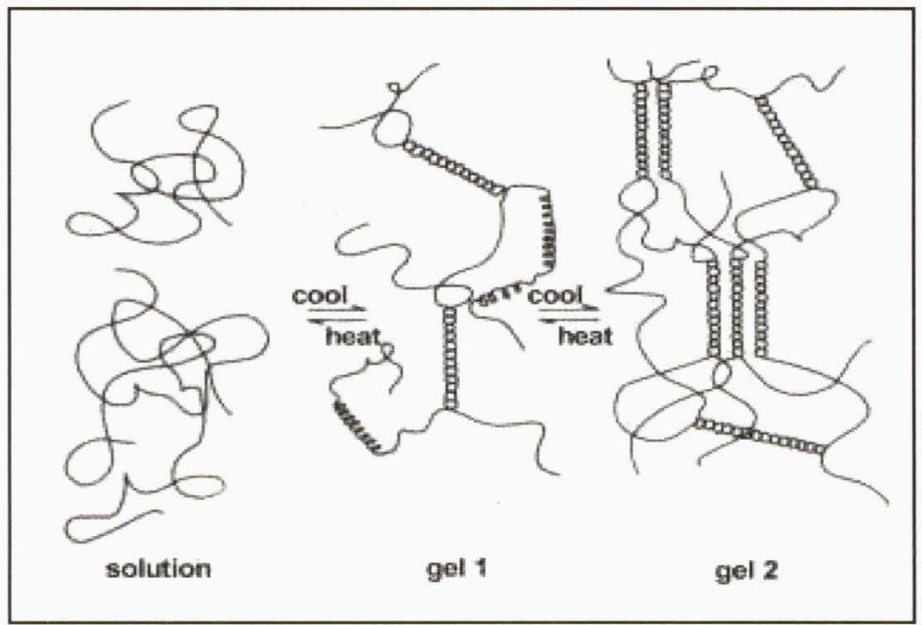

Gambar 5. Pembentukan double helix pada karaginan (Bryce et al., 1974).

Figure 5. Double helix formation in carageenan (Bryce et al., 1974). 
FCC, 1981) yaitu kadar air untuk chip karaginan \pm $12-15 \%$ dan tepung karaginan $10-12 \%$. Kandungan air yang terlalu tinggi dapat menyebabkan terjadinya proses degradasi mutu, karena chip atau tepung karaginan akan mudah ditumbuhi oleh mikroorganisme seperti bakteri dan jamur. Faktor yang mempengaruhi kandungan air di dalam produk karaginan antara lain sistem pengeringan, sifat bawaan produk seperti adanya ion yang bersifat higroskopis dan adanya faktor perlakuan dalam proses pembuatan chip atau tepung karaginan seperti penggunaan bahan kimia ( $\mathrm{NaCl}, \mathrm{KOH}$, dan $\mathrm{NaOH}$ ) yang mudah sekali menyerap uap air dari udara ke dalam produk karaginan. Nilai kadar air karaginan dalam perlakuan ini berkisar antara 8,3-15,9\%, dengan nilai terendah pada perlakuan daur ulang ke-3 sebesar $8,3 \%$ dan tertinggi pada perlakuan penggunaan air daur ulang yang ke-5 sebesar 15,9\% (Gambar 6).

Terjadinya fluktuasi kadar air karaginan untuk setiap perlakuan mungkin disebabkan telah terjadi double helix dalam karaginan akan memperkuat ikatan air dengan gugus karaginan yang mengakibatkan air dari dalam karaginan sukar menguap. Dalam percobaan ini kadar air pada masing-masing perlakuan berfluktuasi, hal ini mungkin disebabkan penyerapan ion-ion logam $\mathrm{Al}^{3+}, \mathrm{Na}^{+}$, dan $\mathrm{Ca}^{2+}$ tidak maksimal.

\section{Kadar sulfat}

Hasil percobaan menunjukkan nilai kadar sulfat meningkat tajam pada perlakuan penggunaan air daur ulang, kemudian cenderung stabil hingga perlakuan penggunaan air daur ulang ke-5 (Gambar 7). Kadar sulfat SRC yang dihasilkan berkisar antara 3,3-3,9\% dengan nilai terendah pada kontrol dan tertinggi pada pemakaian daur ulang yang ke-5. Rata-rata peningkatan kadar sulfat 0,55-0,65\% (Gambar 7). Adanya peningkatan ini kemungkinan disebabkan sejumlah sulfat dari air hasil daur ulang telah tertarik ke dalam thallus rumput laut selama proses

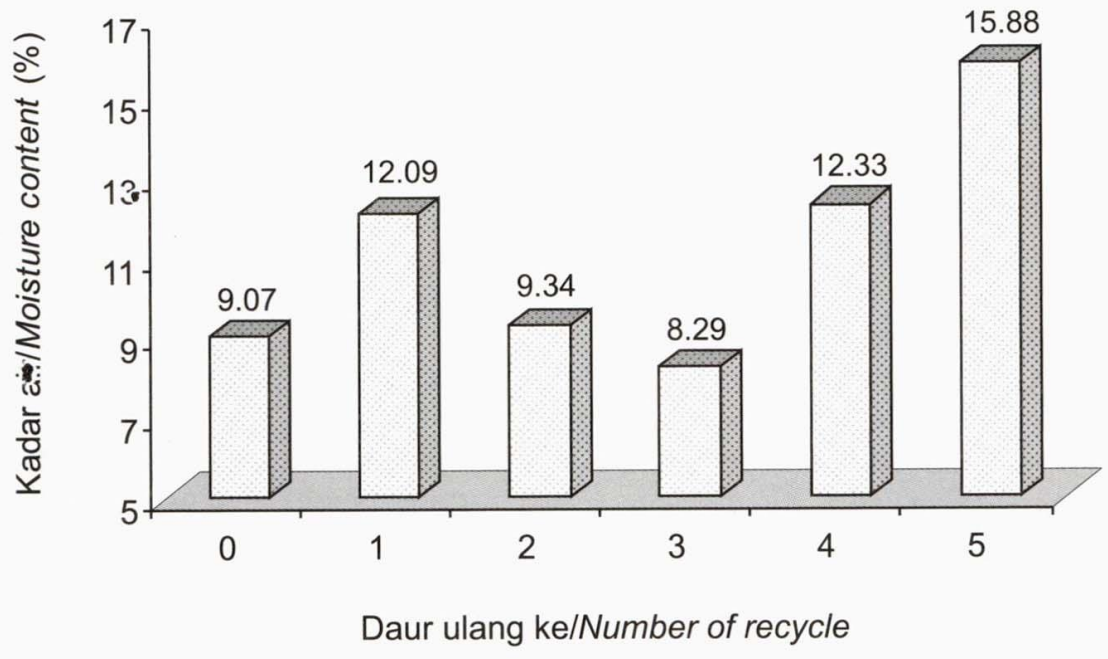

Gambar 6. Kadar air SRC yang diolah menggunakan air daur ulang.

Figure 6. Moisture content of SRC processed using recycled water.

perubahan fisik pada karaginan akibat perlakuan dengan air daur ulang. Adanya logam atau garam di dalam karaginan akan menyebabkan struktur karaginan menjadi berubah seperti ion $\mathrm{Ca}^{2+}$ yang dapat menyebabkan karaginan lebih rigid sehingga kemampuan mengikat air lebih kuat. Dalam proses daur ulang air limbah pengolahan rumput laut digunakan tawas $\left(\mathrm{Al}_{2}\left(\mathrm{SO}_{4}\right)_{3}\right)$ untuk menjernihkan air dan mengendapkan padatan di dalam air limbah. Kemungkinan kelebihan tawas di dalam proses penjernihan air dan pengendapan padatan telah menyebabkan terjadinya fluktuasi kandungan air di dalam SRC. Adanya kelebihan logam seperti ion $\mathrm{Al}^{3+}$, $\mathrm{Na}^{+}, \mathrm{Ca}^{2+}$, dan $\mathrm{Mg}^{2+}$ dapat menghambat terjadinya proses penguapan air dari dalam karaginan. Ikatan pencucian. Adanya sulfat di dalam air hasil daur ulang disebabkan pemakaian tawas $\left(\mathrm{Al}_{2}\left(\mathrm{SO}_{4}\right)_{3}\right)$ yang digunakan untuk proses koagulasi padatan dan penjernihan air. Air limbah pengolahan yang mengandung $\mathrm{KOH}$ bersifat alkali dengan nilai $\mathrm{pH} 12-$ 12,4. Tawas dengan $\mathrm{KOH}$ dapat bereaksi membentuk $\mathrm{K}_{2} \mathrm{SO}_{4}$ dan $\mathrm{Al}(\mathrm{OH})_{3}$. Potasium sulfat di dalam air dapat terdisosiasi menjadi ion $\mathrm{K}^{+}$dan $\mathrm{SO}_{4}{ }^{2-}$.

Pengeringan hanya bertujuan untuk mereduksi zatzat mudah menguap sedangkan ion sulfat akan terdeposit di dalam thallus sehingga menyebabkan kadar sulfat di dalam thallus meningkat. Namun demikian jika dibandingkan dengan spesifikasi yang dikeluarkan oleh FCC (1981) kadar sulfat tersebut masih memenuhi persyaratan. 


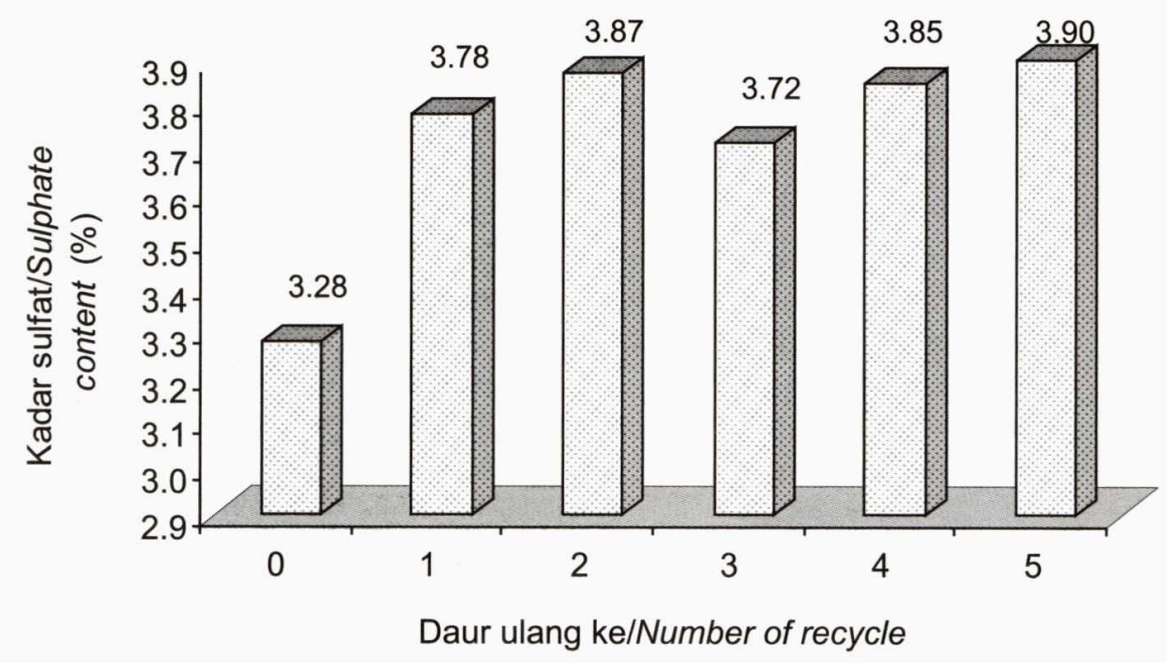

Gambar 7. Kadar sulfat SRC yang diolah menggunakan air daur ulang.

Figure 7. Sulphate content of SRC processed using recycled water.

\section{Kadar abu}

Telah diketahui bahwa alga laut/rumput laut banyak mengandung mineral seperti $\mathrm{Na}^{+}, \mathrm{K}^{+}, \mathrm{Ca}^{2+}$, dan $\mathrm{Mg}^{2+}$. Di.samping itu teknik pengolahan juga akan menentukan kandungan kadar abu produknya. Kadar abu yang dihasilkan pada penelitian penggunaan air daur ulang untuk proses pencucian berfluktuasi. Kadar abu terendah ditemukan pada kontrol, sedangkan yang tertinggi ditemukan pada penggunaan air daur ulang ke-2. Kisaran kadar abu yang ditemukan dalam produk SRC yang dihasilkan pada penelitian ini adalah antara $13-17 \%$ seperti yang terlihat pada Gambar 8. Menurut FCC (1981) persyaratan kadar abu di dalam produk rumput laut maksimum $35 \%$, oleh karena itu, kadar abu semua perlakuan masih dalam batas yang diperbolehkan.
Faktor yang menyebabkan terjadinya peningkatan nilai kadar abu SRC yang dihasilkan disebabkan oleh penggunaan air daur ulang limbah secara berulang. Kemungkinan lain disebabkan karena pada proses pendaur ulangan yang ke-1 hingga ke-5 telah terjadi penyaringan yang kurang efektif sehingga konsentrasi tawas masih tinggi di dalam air daur ulang yang berdampak pada fluktuasi peningkatan kadar abu di dalam produk SRC yang dihasilkan.

\section{Kadar abu tak larut asam}

Adanya abu tak larut asam (ATA) dalam produk SRC adalah suatu indikasi terjadinya kontaminasi yang dapat berupa mineral dan atau logam berat yang tak larut asam selama proses pengolahan. Logam atau mineral tersebut dapat berasal dari bahan baku

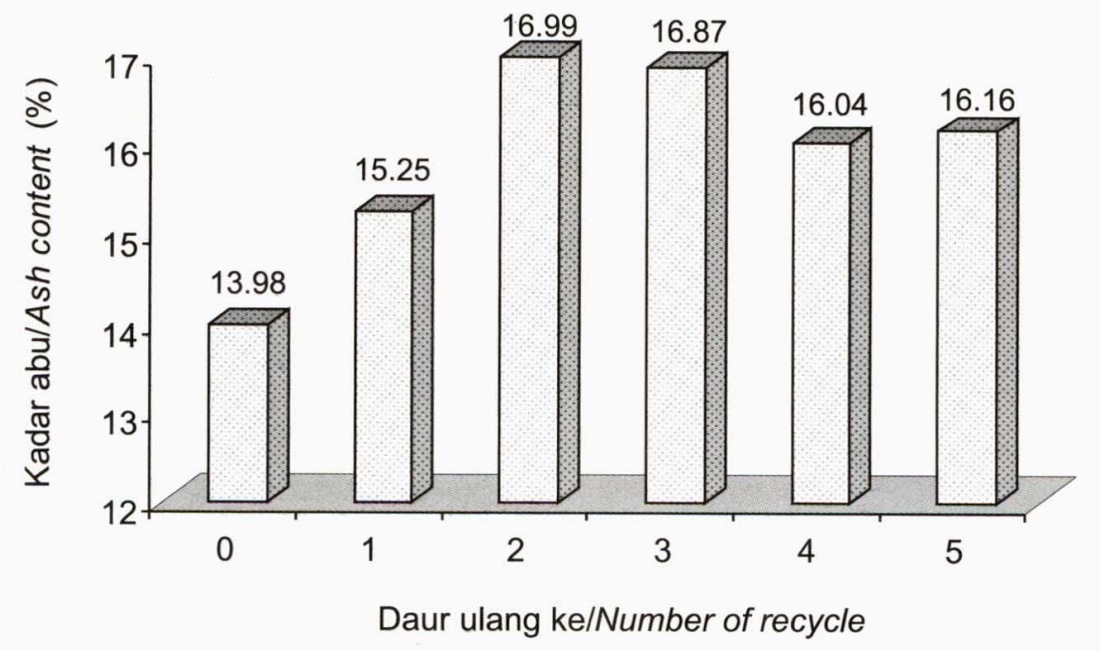

Gambar 8. Kadar abu SRC yang diolah menggunakan air daur ulang. Figure 8. Ash content of SRC processed using recycled water. 


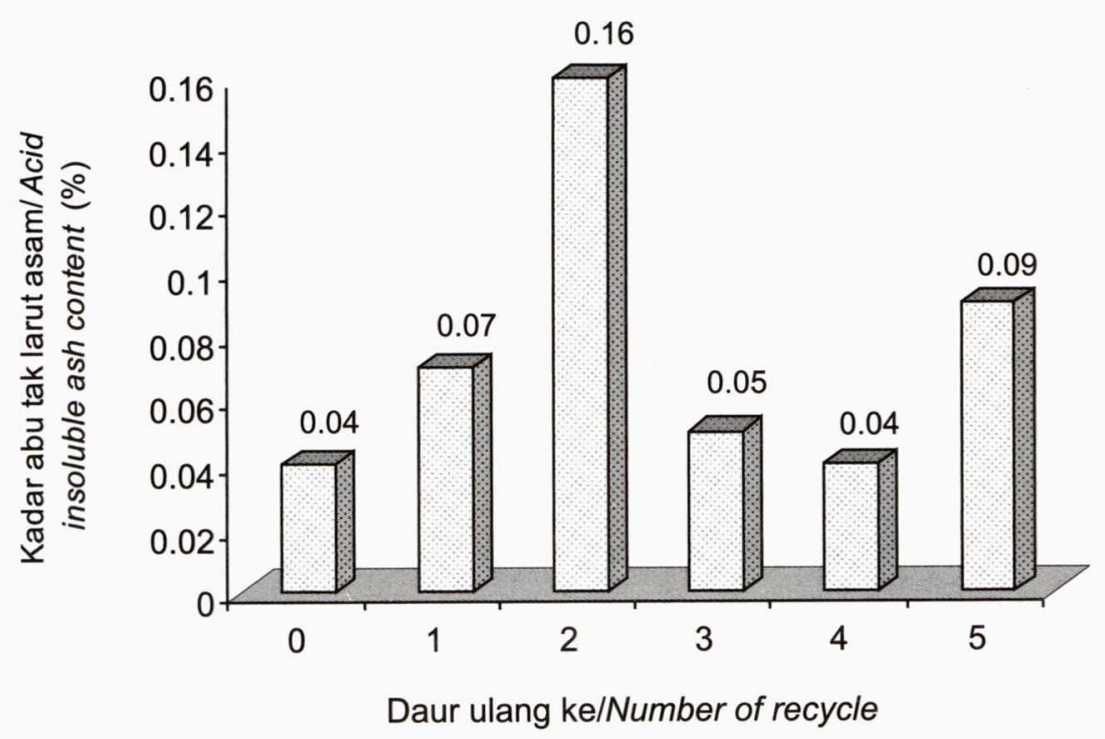

Gambar 9. Kadar abu tak larut asam SRC yang diolah menggunakan air daur ulang.

Figure 9. Acid insoluble ash content of SRC processed using recycled water.

rumput laut yang diproses, air, peralatan yang digunakan, bahan kimia dan atau reaksi antara bahan kimia dengan peralatan yang digunakan. Jika peralatan yang digunakan tersebut mudah bereaksi dengan bahan kimia misalnya peralatan yang mengandung aluminium, akan bereaksi dengan potasium hidroksida membentuk aluminium hidroksida. Persyaratan abu tak larut asam oleh FCC (1981) di dalam produk SRC adalah tidak lebih dari $1 \%$. Nilai ATA di dalam percobaan penggunaan air daur ulang berkisar antara $0,04-0,16 \%$ dengan nilai terendah ditemukan pada kontrol sebesar 0,04\% sedangkan tertinggi ditemukan pada penggunaan air daur ulang yang ke-2, namun demikian secara keseluruhan nilai ATA setiap batch pengolahan berfluktuasi (Gambar 9). Nilai ATA yang diperoleh dari penggunaan air daur ulang masih di bawah standar FCC (1981).

Peningkatan nilai ATA pada perlakuan penggunaan air daur ulang dibandingkan kontrol kemungkinan disebabkan oleh faktor proses penjernihan air yang kurang efektif dan adanya kelebihan tawas $\left(\mathrm{Al}_{2}(\mathrm{SO} 4)_{3}\right)$ pada saat penetralan limbah cair pengolahan rumput laut menjadi SRC. Ion $\mathrm{Al}^{3+}$ merupakan logam yang tidak larut asam sehingga dalam proses pencucian rumput laut yang sudah mendapatkan perlakuan basa, ion tersebut akan berpenetrasi ke dalam thallus rumput laut selama proses pencucian (penetralan). Tawas dengan potasium hidroksida akan bereaksi membentuk aluminium hidroksida $\left(\mathrm{Al}(\mathrm{OH})_{3}\right)$ yang merupakan hasil samping dari proses penetralan limbah cair menggunakan tawas. Pada saat proses pengeringan sejumlah air menguap namun demikian logam yang terbentuk $\left(\mathrm{Al}(\mathrm{OH})_{3}\right)$ terakumulasi di dalam thallus rumput laut, sebagai akibatnya nilai ATA akan meningkat. Di samping itu, kelebihan pemberian tawas selama proses daur ulang dan kurang efektifnya bahan penyaring juga memberikan kontribusi dalam peningkatan nilai ATA di dalam produk SRC yang dihasilkan. Kemungkinan penyebab tingginya nilai ATA pada perlakuan daur ulang ke-2 dibandingkan dengan perlakuan daur ulang lainnya adalah adanya kelebihan pemberian tawas pada saat proses daur ulang dan kurang sempurnanya proses penyaringan yang diberikan.

\section{Kekentalan}

Suspensi koloid dalam larutan dapat meningkat dengan cara mengentalkan cairan sehingga terjadi absorbsi dan pengembangan koloid (Glicksman, 1969). Pada prinsipnya pengukuran kekentalan adalah mengukur ketahan-gesekan antar dua lapisan molekul yang berdekatan. Kekentalan yang tinggi dari suatu material disebabkan karena gesekan internal yang besar sehingga cairan mengalir. Menurut Ostwald (1922) dalam Glicksman (1969), kekentalan hidrokoloid dipengaruhi oleh beberapa faktor yaitu konsentrasi, temperatur, tingkat dispersi, kandungan sulfat, inti elektrik, teknik perlakuan, dan keberadaan elektrolit. Menurut Towle (1973) tipe karaginan dan bobot molekul karaginan juga merupakan faktor yang mempengaruhi kekentalan suatu cairan. Garamgaram akan menurunkan kekentalan karaginan dengan cara menurunkan tolakan elektrostatik di antara gugus sulfat (Guiseley et al., 1980 dalam Luthfy, 1988). Hasil penelitian menunjukkan bahwa nilai kekentalan SRC bervariasi setelah menggunakan air daur ulang untuk pencucian. Nilai kekentalan 


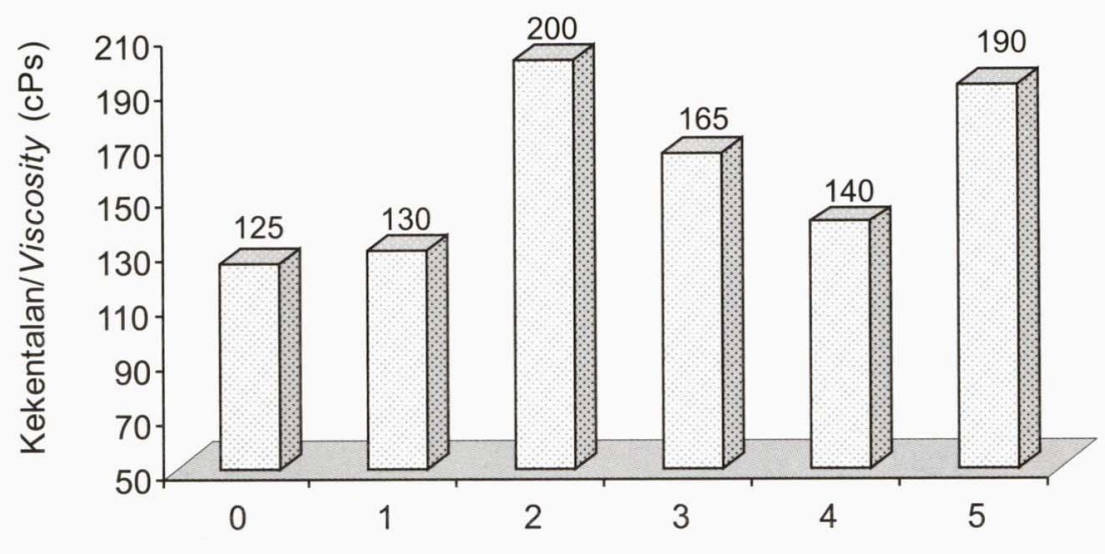

Daur ulang ke/Number of recycle

Gambar 10. Nilai kekentalan SRC yang diolah menggunakan air daur ulang

Figure 10. Viscosity value of SRC processed using recycled water

berkisar antara $125-200 \mathrm{cPs}$. Nilai kekentalan SRC meningkat pada perlakuan penggunaan air daur ulang ke-2, kemudian cenderung terjadi penurunan nilai kekentalan hingga perlakuan penggunaan air daur ulang ke-5. Nilai terendah ditemukan pada perlakuan kontrol sebesar $125 \mathrm{cPs}$ dan tertinggi pada perlakuan menggunakan air daur ulang ke-2 sebesar $200 \mathrm{cPs}$ (Gambar 10).

Moirano (1977) mengemukakan bahwa semakin kecil kandungan sulfat maka nilai kekentalan juga semakin kecil, tetapi konsistensi gel semakin meningkat. Gaya tolak menolak antara grup ester sulfat yang bermuatan sama (negatif) di sepanjang rantai polimer menyebabkan rangkaian molekul kaku dan tertarik kencang sehingga molekul-molekul air terikat pada molekul karaginan yang mengakibatkan meningkatnya kekentalan.

Kelebihan pemberian tawas $\left(\mathrm{Al}_{2}\left(\mathrm{SO}_{4}\right)_{3}\right)$ pada saat proses daur ulang akan menyebabkan terjadinya peruraian $\left(\mathrm{Al}_{2}\left(\mathrm{SO}_{4}\right)_{3}\right)$ menjadi $\mathrm{Al}^{3+}$ dan $\mathrm{SO}_{4}{ }^{2-}$. Adanya ion $\mathrm{SO}_{4}{ }^{-}$berlebihan di dalam air yang sudah didaur ulang akan bereaksi dengan karaginan yang sedang dicuci. Tinggi rendahnya nilai kekentalan SRC yang dihasilkan sangat dipengaruhi oleh banyaknya gugus sulfat pada rantai karaginan (Gambar 11). Semakin tinggi nilai kekentalan menunjukkan indikasi banyaknya ion sulfat yang bereaksi dengan karaginan. Kemungkinan penyebab tingginya nilai kekentalan pada perlakuan daur ulang ke-2 disebabkan oleh ion sulfat yang berlebihan di dalam air daur ulang yang sudah dibersihkan.

\section{KESIMPULAN}

Hasil penelitian menunjukkan bahwa air limbah pencucian rumput laut pada proses pengolahan rumput laut E. cottonii menjadi SRC masih dapat dimanfaatkan untuk pencucian rumput laut pada proses lanjutan pengolahan SRC berikutnya. Penggunaan air daur ulang untuk pengolahan SRC berikutnya masih menunjukkan mutu produk yang baik ditinjau dari kekuatan gel dengan larutan $\mathrm{KCl} 0,1 \%$. Penggunaan air daur ulang hingga 5 kali proses daur ulang masih dapat meningkatkan kekuatan gel dengan larutan $\mathrm{KCl} 0,1 \%$, dan parameter lainnya masih dalam

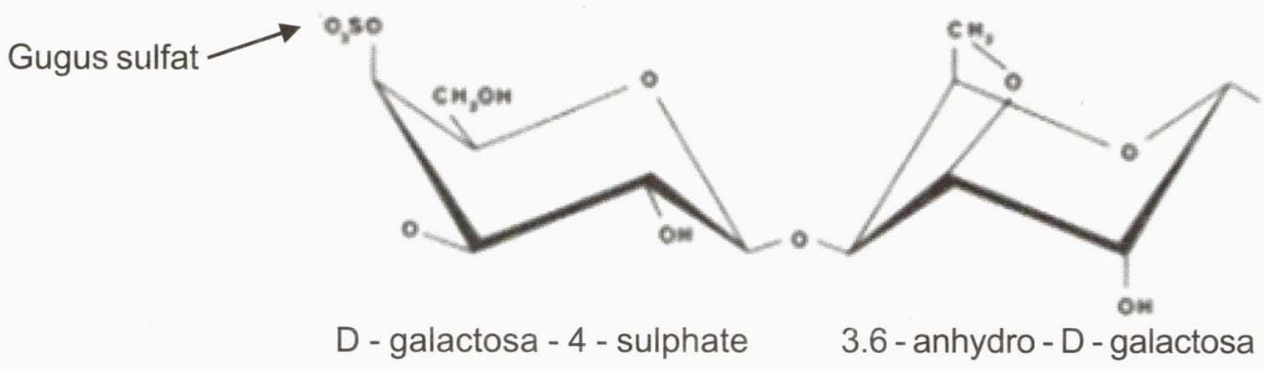

Gambar 11. Rumus molekul karaginan dengan gugus sulfat (cPKelco ApS, 2004).

Figure 11. Molecular structure of carrageenan with sulphate group (cPKelco ApS, 2004). 
standar (FCC, 1981). Namun demikian, di antara perlakuan tersebut kualitas SRC yang terbaik ditemukan pada proses pemakaian air daur ulang yang ke-4 dengan nilai kekuatan gel menggunakan larutan $\mathrm{KCl} 0,15$ adalah $1147 \mathrm{~g} / \mathrm{cm}^{2}$, kadar abu $16,0 \%$, kadar abu tak larut asam $0,04 \%$, kadar sulfat 3,9\%, dan kadar air $12,3 \%$.

\section{DAFTAR PUSTAKA}

Anonymous. 1986. Specification for identify and purity of certain food additives. FAO and Nutrition Paper. 34: $17-22$.

Anonymous. 1991. Technical Q \& A. Infofish. 3: 64-65.

Anonymous. 2007. Carrageenans. http://www.lsbu.ac.uk/ water/hycar.html. Diakses tanggal 19 April 2007.

Anonymous. 2009. Gelling mechanism. http://www. Gelling_mechanism.htm. Diakses Januari 2009.

cPKelco ApS. Carrageenan. Denmark. http:// www.cPKelco.com. Diakses tanggal 15 Agustus 2004.

Bakti, B.S., Basmal, J., dan Fithriani, D. 2007. Ujicoba proses daur ulang limbah cair ATC (Alkali Treated Cottonii) dengan teknik koagulasi dan filtrasi. Jurnal Pascapanen dan Bioteknologi Kelautan dan Perikanan. 2(2): 107-115.

Basmal, J., Syarifuddin, dan Ma'ruf, W.F. 2003. Pengaruh konsentrasi larutan potassium hidroksida terhadap mutu kappa-karaginan yang diekstraksi dari Eucheuma cottonii. J. Penel. Perik. Indonesia. 9(5): 95-103.

Bryce, T.A.,Mckinnon, A.A., Morris, E.R., Rees, D.A., and Thom, D. 1974. Chain Conformations in the Sol-Gel Transitions for Polysaccharide system and their Characterisations by Spectroscopic Methods.
Unilever research ColworthWelwyn Laboratory, Colworth House, Sharnbrook, Bedford MK 1 44LK. Offprinted by faradays Discussion of the Chemical Society, No. 57. p. 1-9.

Dea, I.C.M. 1979. Polysaccharides in Food. In Blanshard and Mitchell, J.R. (eds.). Academic Press, Washington. p. 229-246.

FCC. 1981. Carrageenan. Food Chemical Codex. National Academy Press, Washington. p. 74-75.

Glicksman, 1983. Food Hydrocolloid. II. CRC Press, Bocaraton, Florida. $183 \mathrm{pp}$.

Glicksman, 1969. Gum Technology in The Food Industry. Academic Press, New York. p. 102-110.

Horwitz. 1980. Official Methods of Analysis on the Association of Official Analytic Chemist. Horwitz, 1981 (ed.). Washington D.C. 550 pp.

Luthfy, S. 1988. Mempelajari Ekstraksi Karaginan Dengan Metode "semi refine" dari Eucheuma cottonii. Fakultas Teknologi Pertanian, IPB, Bogor. $106 \mathrm{pp}$.

Marine Colloid. 1977. Raw Material Test Laboratory Standard Practice. Marine Colloid div. Corp. Springfield, New Jersey, USA.

Moirano, A.L. 1977. Sulphate polysaccharides. In Graham, H.D. (ed.). Food Colloids. The AVI Publisher Co. Inc. Westport, Connecticut. p. 347-381.

Suryaningrum, T.D., Murdinah, dan Erlina, M.D. 2003. Pengaruh perlakuan alkali dan volume larutan pengekstrak terhadap mutu karaginan dan rumput laut Eucheuma cottonii. J. Penel. Perik. Indonesia. 9(5): 65-76.

Towle. 1973. Carrageenan. In Whisler (ed.). Industrial Gums: Polysaccahrides and Their Derivatives. Academic Press, New York. p. 85-109. 